\title{
Journal of Educational Sciences
}

\section{Students' Creativity in Creating Aromatherapy Candle using Petroleum Learning Design with Radec Model}

Wulandari*, Wawan Wahyu, Wahyu Sopandia

Chemistry Education, School of Postgraduate, Universitas Pendidikan Indonesia, Bandung, 40154, Indonesia

\section{ARTICLE INFO}

\section{Article history:}

Received: 06 July 2020

Revised: 12 Oct 2020

Accepted: 13 Oct 2020

Published online: 24 Oct 2020

\section{Keywords:}

Creativity

Learning Design

RADEC

Petroleum

\begin{abstract}
A B S T RA C T
The purpose of this study was to observe whether the examined learning design can improve students' creativity. at the petroleum lesson by using the examined learning design. This research was conducted in Madrasah Aliyah Negeri 2 Takengon. The preferred samples were three second-grade students, a chemical teacher, and two expert lecturers. In this study, the method was descriptive. as it involved two experts, who were lecturers, a chemical teacher, and three second-grade high school students. The data collections were carried out through external and internal feasibility tests. An internal feasibility test was conducted on the chemistry teacher and two expert lecturers, while an external feasibility test was conducted on the three second-grade students. Based on the results, the score results in almost every RADEC stage with a percentage of $91.6 \%$ and categorized as very strong, except for the sub-indicator of development creativity or enriching ideas acquired scores of $83.3 \%$. These results imply that petroleum oil learning design with the RADEC model is applicable in the learning process to develop students' creativity. students' creativity could be improved by applying chemical learning that uses this learning design.
\end{abstract}

\section{Introduction}

The 4.0 Industrial Revolution is already a popular term among in society. In Indonesia, the boost of information and technology occurs very quickly. condition in the 21 st century. This revolution is marked by technological improvement in every sector. One of them is the education field. In this age, technology and information affect school activities very quickly. New information and knowledge spread quickly and accessible to every circle, so that the teachers' role who has been acting as knowledge providers was shifted slowly. Therefore, the current applied curriculum in the school is expected for the students mastering skills, 
namely: critical thinking, communication, collaboration, and creativity in solving problems.

The importance of creative aspects to human life makes the study of creativity an essential topic for various groups ranging from public policymakers, scientists, researchers, to practitioners. According to Amabile \& Pratt (2016), a person's creativity can be found from interests, pleasures, satisfaction, and challenges from a job, not coming from pressure or other social environments. The goals of creativity are to make the students learn chemistry with joyful and full-interaction in the scientific learning process.

Wahyu (2015) stated that to establish the characters of Indonesia's young generation, we need to prioritize character education in the way it can support the noble values of the Indonesia nation. In chemistry learning, the proposed character education does not refer to the moral and religious character education. Yet, it refers to the scientific attitude of a scientist, for example, creativity. Creativity is also included in one of the eighteen character values in Indonesia's education system. Wahyu (2018) states that learning activities that emphasize creativity allow students to conduct research and solve problems in their own learning situations. $\mathrm{n}$ addition, in preparing today's children to excel and solve problems in the success of the 21 st century, the value of creativity must be cultivated (Beghetto \& Sriraman, 2017).

One of the topics of Chemical taught in the second grade of high school is petroleum. Petroleum is a mixed material from various hydrocarbon. In separating petroleum, the raw oil, which is a mixture of all components, will be separated from each component, which is a hydrocarbon-based on different boiling points. One of the petroleum processing products is a candle. The structure of a candle has a length of alkane carbon chain numbered twenty carbon atoms. In provide creativity, students are guided to produce an aromatherapy candle product.

To improve students' creativity, previous researchers have created and examined some learning models in the past. According to Happy (2014), the learning model of problem-based learning (PBL) could be more effective in improving creativity than conventional learning. The other learning models are the inquiry learning model and Project-Based Learning (PjBL). However, this innovative learning does not directly fix current Indonesia's education quality. The factor is, probably, the teachers having sort of obstacles in applying those innovative learning models. Thus, we can say there is a problem in Indonesia's education process.

Indonesia's education system has very different issues from other countries' education issues. Sopandi et al. (2017) state that teachers have difficulty in applying innovative learning from other countries. One of the causes is the difficulty in memorizing the stages in those models. Sopandi et al. (2019) add that not every learning models are well known to all participants, and all participants know only $20 \%$ of learning cycles. Thus, the solution is to implement a learning model that is appropriate to Indonesian context. The learning model is RADEC. 
There are previous studies that used the RADEC model in improving creativity, as well. Siregar (2019) used and stated that the RADEC model learning design with STEM-oriented is categorized as high to improve students' creativity and problem-solving. In developing students' creativity, this RADEC model is affecting its stages, which is "create." In this stage, students are guided to produce a creation or a product to improve their creativity. With that in mind, this research uses the RADEC model to observe whether there was any improvement in students' creativity at the petroleum lesson by using the examined learning design.

\section{Methodology}

The method of this study was descriptive. A descriptive approach is a method that aims at describing the existing phenomena, which took place at the present or in the past. Sugiyono (2005) states that a descriptive method is purposed to describe or analyze specific research outcomes, but it does not use to draw a broader conclusion.

The participants of this study were two lecturers, a chemistry teacher, and three second-grade high school students in Madrasah Aliyah Negeri 2 Takengon. The data collection was carried out through external and internal feasibility tests. The feasibility criteria was graded by using feasibility criteria according to Wiersma and Jurs (2009), then the data was assessed and processed into scores and interpreted using score interpretations, according to Riduwan (2015). The internal feasibility test was conducted on two lecturers and a chemistry teacher using Williams's creativity sub-indicator (Munandar, 1992), which consisted of fluencythinking, flexibility, original-thinking, elaboration, and evaluation. Meanwhile, the external feasibility test was carried out by three students by making aromatherapy candle products.

The instruments of this study were TCOF, feasibility tests of petroleum learning design, and questionnaires. The collected data were tabulated, and the interpretation of feasibility test scores and questionnaires were categorized according to Riduwan score interpretation. Meanwhile, the interpretation of TCOF scores was categorized according to Al Abdali \& Al Balushi score interpretation.

\section{Results and Discussion}

Petroleum learning in this study is purposed to observe students' creativity. This creativity can be improved through one method, which is product creation. The created product was an aromatherapy candle. A candle is a product made from petroleum. The creation of the aromatherapy candle was done by the students individually. The process started with choosing tools and materials and working procedures in making the candle. The outcomes of this study were students created aromatherapy products from coffee beans and Etlingera Elatior flowers. The reason for choosing these materials was because of a district in central Aceh, 
Gayo, the biggest coffee producer in Aceh province. On the other side, the Etlingera Elatior flower is easy to find.

\section{Petroleum Learning Design}

In this learning, the design was made according to the syntax of the RADEC model. The syntax consisted of five stages: Read, Answer, Discuss, Explain, and Create with the STEM approach based on google classroom. The findings obtained from every syntax of the RADEC model can be seen in the following table 1.

Table 1. Findings from each RADEC model on learning design

\begin{tabular}{|c|c|}
\hline Syntax & Findings \\
\hline Read & $\begin{array}{l}\text { Students read about petroleum material from various sources at their home. } \\
\text { These sources made the students had preliminary knowledge about petroleum } \\
\text { material, and therefore the learning was more effective once it has done. }\end{array}$ \\
\hline Answer & $\begin{array}{l}\text { Students answered questions in LKS-1, which the teacher has uploaded on } \\
\text { Google classroom. In this stage, students answered the items individually, } \\
\text { which trained them to be independent and responsible. Also, in this stage, } \\
\text { students wrote down the problems they encountered in petroleum learning, } \\
\text { which made it easier for the teachers to know their obstacles during the } \\
\text { learning. }\end{array}$ \\
\hline Discuss & $\begin{array}{l}\text { Students made discussions with their friends in a group to produce a joint } \\
\text { answer decision. After the students found an agreement, the note-taker } \\
\text { immediately sent the answers to the virtual classroom after a question had been } \\
\text { discussed. It also went the same to other questions. }\end{array}$ \\
\hline Explain & $\begin{array}{l}\text { In this stage, students were given the opportunity by the teacher to explain their } \\
\text { group's answers. At this stage, students were trained on their self-confidence } \\
\text { and responsibility for the answers they provide. }\end{array}$ \\
\hline Create & $\begin{array}{l}\text { Students designed aromatherapy candle projects. The design was created as the } \\
\text { result of student discussions to determine the tools and materials as well as the } \\
\text { steps needed in creating the project. The final design was uploaded then } \\
\text { to Google classroom. }\end{array}$ \\
\hline
\end{tabular}

In this study, the creativity indicator used was Williams's creativity indicator, which consisted of fluency-thinking, original-thinking, elaboration, and evaluation. The feasibility test result conducted by experts and teachers for the suitability of learning activities with Williams's creativity sub-indicator is shown in Table 2 below. 
Tabel 2. The suitability of learning activities with Williams's creativity subindicators

\begin{tabular}{|c|c|c|c|c|}
\hline $\begin{array}{c}\text { RADEC } \\
\text { model } \\
\text { syntax }\end{array}$ & Learning Activities & $\begin{array}{l}\text { Creativity } \\
\text { Sub } \\
\text { Indicators }\end{array}$ & Score & Category \\
\hline Read & $\begin{array}{l}\text { Students marked concepts that } \\
\text { had not been mastered in } \\
\text { petroleum material. }\end{array}$ & $\begin{array}{l}\text { Thinking } \\
\text { about } \\
\text { problems that } \\
\text { no one else } \\
\text { thinks. }\end{array}$ & $91.6 \%$ & $\begin{array}{l}\text { Very } \\
\text { strong }\end{array}$ \\
\hline Answer & $\begin{array}{l}\text { Students collected answers } \\
\text { to pre-teaching questions in } \\
\text { LKS-1, as a discussion } \\
\text { material for the next meeting } \\
\text { before the learning begins. }\end{array}$ & $\begin{array}{l}\text { Answering } \\
\text { some } \\
\text { questions (if } \\
\text { there is any). }\end{array}$ & $91.6 \%$ & $\begin{array}{l}\text { Very } \\
\text { strong }\end{array}$ \\
\hline Discuss & $\begin{array}{l}\text { Students could communicate } \\
\text { with their classmates about the } \\
\text { answers. }\end{array}$ & $\begin{array}{l}\text { Give a variety } \\
\text { of } \\
\text { interpretations } \\
\text { of an image, } \\
\text { story, or } \\
\text { problem. }\end{array}$ & $91.6 \%$ & $\begin{array}{l}\text { Very } \\
\text { strong }\end{array}$ \\
\hline Explain & $\begin{array}{l}\text { The teacher gave an } \\
\text { opportunity to the group to } \\
\text { communicate the discussion } \\
\text { result of both the answers } \\
\text { to pre-launching } \\
\text { the problems found in the } \\
\text { zoom application. }\end{array}$ & $\begin{array}{l}\text { Smoothly } \\
\text { expressing } \\
\text { their ideas. }\end{array}$ & $91.6 \%$ & $\begin{array}{l}\text { Very } \\
\text { strong }\end{array}$ \\
\hline \multirow[t]{3}{*}{ Create } & $\begin{array}{l}\text { Each group discussed the } \\
\text { project that would be made in } \\
\text { the production of } \\
\text { aromatherapy candles and } \\
\text { filled out the first phase of } \\
\text { LKS-2 (the project design } \\
\text { stage) }\end{array}$ & $\begin{array}{l}\text { Developing or } \\
\text { enriching } \\
\text { other people's } \\
\text { ideas. }\end{array}$ & $83.3 \%$ & $\begin{array}{l}\text { Very } \\
\text { strong }\end{array}$ \\
\hline & $\begin{array}{l}\text { Students wrote down each } \\
\text { group member's } \\
\text { idea, scheduled to work on the } \\
\text { aromatherapy candle project } \\
\text { as a group, and made joint } \\
\text { decisions. }\end{array}$ & $\begin{array}{l}\text { Design a work } \\
\text { plan of ideas } \\
\text { that are } \\
\text { sparked }\end{array}$ & $91.6 \%$ & $\begin{array}{l}\text { Very } \\
\text { strong }\end{array}$ \\
\hline & $\begin{array}{l}\text { Students chose and counted } \\
\text { the materials needed } \\
\text { for the aromatherapy candle } \\
\text { project. Each group chose } \\
\text { different elements from the } \\
\text { other groups. }\end{array}$ & $\begin{array}{l}\text { Chose another } \\
\text { method than } \\
\text { the others }\end{array}$ & $91.6 \%$ & $\begin{array}{l}\text { Very } \\
\text { strong }\end{array}$ \\
\hline
\end{tabular}


Based on the table above, it can be seen that the results of the score from the expert assessment for learning design in the first syntax, which is "read," get a score of $91.6 \%$ and categorized as a very strong. In this stage, almost observers gave "very strong" scores, so the obtained scores are also high. The same count is also obtained at almost all stages of the Radec learning model, except for the creativity sub-indicator developing or enriching other people's ideas with $83.3 \%$. The influencing factor was probably the students who had difficulty in every "developing" or "enriching other people's idea" sub-indicators. This factor became more apparent when a student is looking for a product creation idea; he or she will find relevant information from various sources as a reference to make the product. In making the product, the students will use the obtained reference as the guidebook of making aromatherapy candles. Based on those score results, it implies that the learning design is in accordance with the TCOF instrument used, and therefore, this learning design is feasible to be used in the learning process.

\section{Students' creativity}

The improvement of students' creativity was conducted through an external test. Three students did this test. They are assigned to produce aromatherapy candles. In this case, the development of students' creativity is the production of products which purely made by the students, so in the process, students are guided to develop their creativity. This result can be proven by observing their decision in choosing an idea, tools and materials, and finally, the working procedure. The products made by the students can be seen in the following pictures.

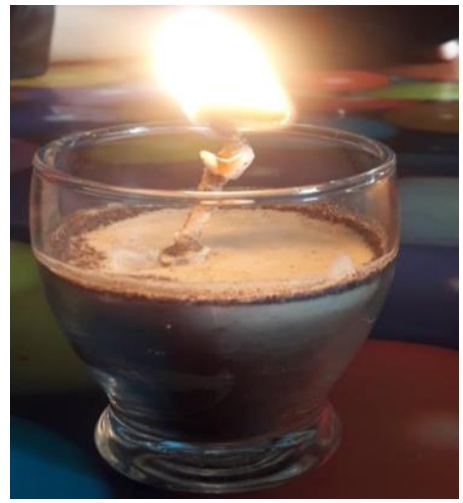

(a)

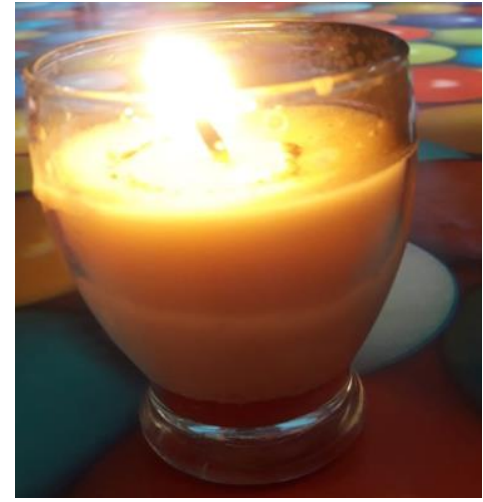

(b)

Figure 1. (a) Product of students' creativity in aromatherapy candles coffee (b) Product of students' creativity in dragon fruit skin wax

The product created by the students can develop their creativity in the way of making a creation. The product made is aromatherapy candles. The production of products is designed by students, starting from the selection of tools and raw materials preferred in the making of aromatherapy candles, and the working procedures used. 


\section{Conclusion}

Based on the conducted research in this study, it can be concluded that based on internal feasibility tests on two expert lecturers and a chemistry teacher where the test has been customized to the learning activity with Williams sub-indicator creativity, the results show that learning design using the RADEC model with STEM approach is categorized as high in developing creativity. Hence, this learning design is very feasible to develop creativity in petroleum learning.

Based on the external feasibility tests, students' creativity in this research is improved as well. The test result can be seen from their product creation. They are independent start from finding an idea to the deciding materials and working procedures.

\section{Acknowledgement}

I would like to gratitude gratefully acknowledge to Mr. Wawan Wahyu and Mr. Wahyu Sopandi as research advisors. As well, I thank the chemistry teacher and students who have participated

\section{References}

Amabile, T. M., \& Pratt, M. G. (2016). The dynamic componential model of creativity and innovation in organizations: Making progress, making meaning. Research in organizational behavior, 36, 157-183.

Beghetto, R. A., \& Sriraman, B. (2017). Creative contradictions in education. Springer.

Happy, N., \& Widjajanti, D. B. (2014). Keefektifan PBL ditinjau dari kemampuan berpikir kritis dan kreatif matematis, serta self-esteem siswa SMP. Jurnal Riset Pendidikan Matematika, 1(1), 48-57.

Riduwan. (2015). Dasar-Dasar Statistika. Bandung: Alfabeta.

Munandar, U. (1992). Mengembangkan Kreativitas dan Bakat Anak. Jakarta: Gramedia.

Siregar, L. (2019). Desain Pembelajaran Polimer Menggunakan Model Read, Answer, Discuss, Explain Dan Create (RADEC) Berbasis Google Classroom Untuk Mengembangkan Penguasaan Konsep Dan Kreativitas Siswa Smk Pada Pembuatan Bioplastik. (Tesis). Universitas Pendidikan Indonesia: Bandung.

Sopandi, W. (2017, September). The quality improvement of learning processes and achievements through the read-answer-discuss-explain-and create learning model implementation. Proceeding 8th Pedagogy International Seminar 2017: Enhancement of Pedagogy in Cultural Diversity Toward Excellence in Education 8(229), 132-139.

Sopandi, W. (2019). Sosialisasi dan Workshop Implementasi Model Pembelajaran RADEC Bagi Guru-Guru Pendidikan Dasar dan Menengah [Dissemination and Implementation Workshop of RADEC Learning Models for Primary 
and Secondary Education Teachers]. Pedagogia: Jurnal Pendidikan, 8(1), 19-34.

Sugiyono. (2005). Metode Penelitian Kuantitatif Kualitatif Dan R\&D. Bandung: Alfabeta.

Wahyu, W. (2015). Peningkatan Efikasi Diri Peserta Didik dalam Pembelajaran Kimia melalui Teknik Jigsaw II. Prosiding Simposium Nasional Inovasi dan Pembelajaran Sains 2015.

Wahyu, W., Suryatna, A., \& Kamaludin, Y. S. (2018). The suitability of William's creativity indicators with the creativity-based worksheet for the junior high school students on designing simple distillation tool. Journal of Engineering Science and Technology (JESTEC), 13(7), 1959-1966.

Wiersma, W., \& Jurs, S. (2009). Research methods in education: An introduction. MA: Pearson.

How to cite this article:

Wulandari, Wahyu, W., \& Sopandia, W. (2020). Students' Creativity in Creating Aromatherapy Candle using Petroleum Learning Design with Radec Model. Journal of Educational Sciences, 4(4), 813-820. 